Bangladesh J. Zool. 41(1): 29-42, 2013

\title{
NEW RECORD OF SOME FRESHWATER MUSSELS (BIVALVIA: UNIONIDAE) FROM NORTH-EAST BANGLADESH
}

\author{
Mahiuddin Md. Shahjahan Bhuiyan*, Md. Redwanur Rahman¹, \\ Md. Sarwar Jahan ${ }^{1}$ and Minu Haque ${ }^{2}$ \\ Barura Shahid Smriti Govt. College, Comilla, Bangladesh
}

\begin{abstract}
A total of 6 species of freshwater mussels under the family Unionidae, order- Unionoida were collected, which are new records for Bangladesh. The information on the distribution and ecology, population density and seasonal variation of Lamellidens phenchooganjensis, L. indawgyiensis, L. generosus, Parreysia (Parreysia) favidens var. assamensis, $P$. (P.) var. marcens and $P$. (P.) var. viridula were provided in this paper. Population density and morphometric parameters were measured. Moreover, economic importance and economic role were stated.

Key words: Freshwater Mussels, Bivalvia, Unionidae, Bangladesh, new records.
\end{abstract}

\section{INTRODUCTION}

Freshwater mussels of the bivalves under order Unionoida have world wide distribution, presently occurring on all non glaciated continents in all types of inland waters. Estimates of global freshwater mussel diversity have in the modern era ranged from less than 850 to 1200 species (Cumming and Graft 2005). Most species are lotic but many species are well suited for lentic environments. The unionids are unique among mussels, having obligate parasitic larval stage on gills, fins or sides of a host fish (Wachtler et al. 2001). Majority of the mussels are infaunal organisms burrowing into substrates varying from sand to gravel but few species exploit the exposed hard surface by attaching to hard surface with byssal threads.

Freshwater mussels are important to both man and the aquatic environment. In one hand, they are filter feeders and act as a natural water cleaners and indicators of water quality (Hua Dan et al. 2001). On the other hand, they are edible to both human and animals. Bivalves remove suspended algae and Particular Organic Matter (POM) from the water column. Mussels process large volumes of water and therefore exposed to dissolved toxic substances such as heavy metals (Imlay 1982, Metcalfe and Green 1992,). Freshwater mussel communities are important components of food webs and they link to multiple trophic levels.

${ }^{*}$ Corresponding author: E-mail: sbhuiyan72@yahoo.com, ${ }^{1}$ Institute of Environmental Science, University of Rajshahi, Rajshahi-6205, Bangladesh. ${ }^{2}$ Dr. Khandaker Mosharraf Hossain College, Daudkandi, Comilla, Bangladesh. 
Our knowledge on freshwater mussels of Bangladesh is very scanty. Ali and Begum (1976) described only four species of bivalves from Dhaka city. Begum et al. (1989) reported 10 species of freshwater mussels from Bangladesh. Begum et al. (1990) studied on pearl culture in freshwater mussel L. marginalis in Fisheries Research Institute Pond, Mymensingh. Recently Siddiqui et al. (2007) described 6 freshwater mussel species of Bangladesh in their book.

Some studies on ecology, population density, conservation, biodiversity and economic importantance of freshwater mussel of the world have been reported by Vaughn and Pyron (1995), Vaughn et al. (2008), Outeitro et al. (2008) and Prez-Quintero (2011). The present study was to identify, morphometrics, population density and economic importance of freshwater mussel collected from Brahmanbaria, Comilla, Habiganj, Moulvibazar, Sylhet and Sunamganj districts of North-East Bangladesh

\section{MATERIAL AND METHODS}

Study area: The Northeastern region of Bangladesh includes the present districts of Brahmanbaria, Comilla, Habiganj, Moulvibazar, Sylhet and Sunamganj. This region covers a land area of $13,938.65$ sq. $\mathrm{km}$ situated between $23^{\circ} 2^{\prime}$ to $25^{\circ} 2^{\prime} \mathrm{N}$ latitude and longitude $91^{\circ} 7^{-}$to $92^{\circ} 41^{\prime} \mathrm{E}$. The region abounds in freshwater systems including wetlands in the floodplains crossed by rivers like Surma, Khusiyara, Peeyain, Saree, Gowain, Khowai, Sonai, Meghana, Titas, Gomoti and their tributaries, tanks, streams, pools and marsh lands (Fig 1).

Triplicate sampling were done in ponds from each districts of Brahmanbaria, Comilla, Habiganj, Maulvibazar and Sylhet and five sampling sites each in the river Surma, Khusiyara, Ratna, Titas and Gomoti representing lotic habitat. From each site three quadrates of $1 \mathrm{~m}^{2}$ area were taken according to the depth of water (viz. $0-50 \mathrm{~cm}, 50-100 \mathrm{~cm}$ and $100-200 \mathrm{~cm}$ ) in respect of Summer, Monsoon and Winter season. A total of 540 quadrates were explored in course of two years (2005-2007) study period.

Collection method: Mussels were collected by hand dredge. By hand picking in cases of bigger specimens from the small ponds and slow moving river. In small ponds the collection made by scooping the bottom mud and then put into sieve and washed with water. Some cases in river samples were collected by Ekman dredge.

Cleaning: Mussels shells were washed and cleaned by (i) Bleeching method: 300 grams of bleeching powder was dissolved in 4 liters of tap water. Shells were left for 24 hours. After the shells were taken on a tray and cleaned foreign particles (sand, mud etc.) by using brush and rewashed. After washing the shells were dried in sunlight. (ii) $\mathrm{HCl}$ acid wash: A mixture of concentrated 
hydrochloric acid and water in ratio of 1:7 was prepared. Treatment time depends upon the thickness and dirtiness of the shells. After acid wash the shells were dried in sunlight.

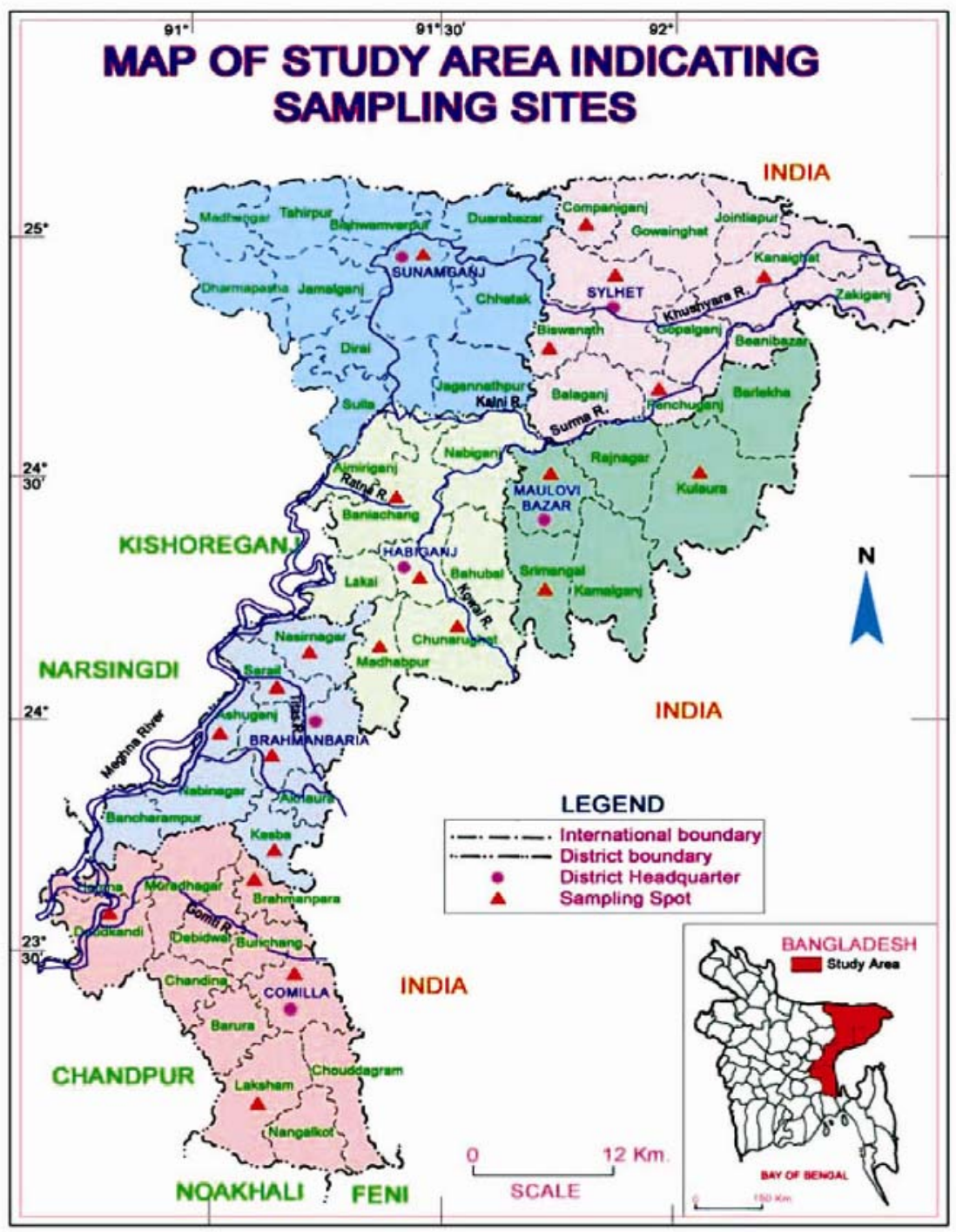

Fig 1. Map of Northeastern region indicating sampling sites

Preservation: For biometric analysis mussels were preserved in the $70 \%$ ethyl alcohol in plastic jars for futher studies.

Identification: Dry shells were separated on the basis of similarities and dissimilarities of characters and packed in small polythyne bags and records 
were maintained. Then following books viz., Preston (1915), Subba (1989) and Ramakrishna and Dey (2007) were consulted for identification of species and confirmed from the Mollusca Division of the Zoological Survey of India, Kolkata.

Morphometrics: Various morphometric measurements were taken with the help of a divider and slide calipers from randomly collected species from the natural habitats. Photographs were taken by Olympus FE-230.

\section{RESULTS AND DISCUSSION}

Six freshwater mussel species belonging to the two genera of Unionidae family, order-Unionida under class Bivalvia were recorded for the first time from Bangladesh. The species were Lamellidens phenchooganjensis, L. indawgyiensis, L. generosus, Parreysia (Parreysia) favidens var. assamensis, P. (P.) var. marcens and $P$. (P.) var. viridula. Population densities are presented in the Table 1.

The population density of $L$. phenchooganjensis was found highest $\left(2.66 / \mathrm{m}^{2}\right)$ in winter in Khushiyara River and lowest $\left(0.22 / \mathrm{m}^{2}\right)$ in monsoon and summer in both Khusyara and Ratna River. L. generosus was found only in a pond of Habiganj. The population density of $L$. generosus was highest $\left(1.60 / \mathrm{m}^{2}\right)$ in winter and lowest $\left(0.66 / \mathrm{m}^{2}\right)$ in monsoon in the same pond of Habiganj. $L$. indawgyiensis, $P$. favidens var. assamensis, $P$. (P.) favidens var. marcens, $P$. favidens var. viridula were found sporadic in distribution. So their population density could not be recorded.

Identification key of mussels species found in the north eastern region of Bangladesh.

\section{Key to Class Bivalvia}

1 Shell internally nacreous

- Shell internally non-nacreous

2 Beak sculputer concentric-radial and rudimentary; only two outer gills marsupials Unionidae

- Beak sculpture radial and well developed; all four gills marsupials Amblemidae

3 Shell thick, and strong, with strong and blunt ribbing, above $10 \mathrm{~mm}$ thickness Corbiculidae

- Shell thin, and fragile, with fine ribbings, below $10 \mathrm{~mm}$ thickness 


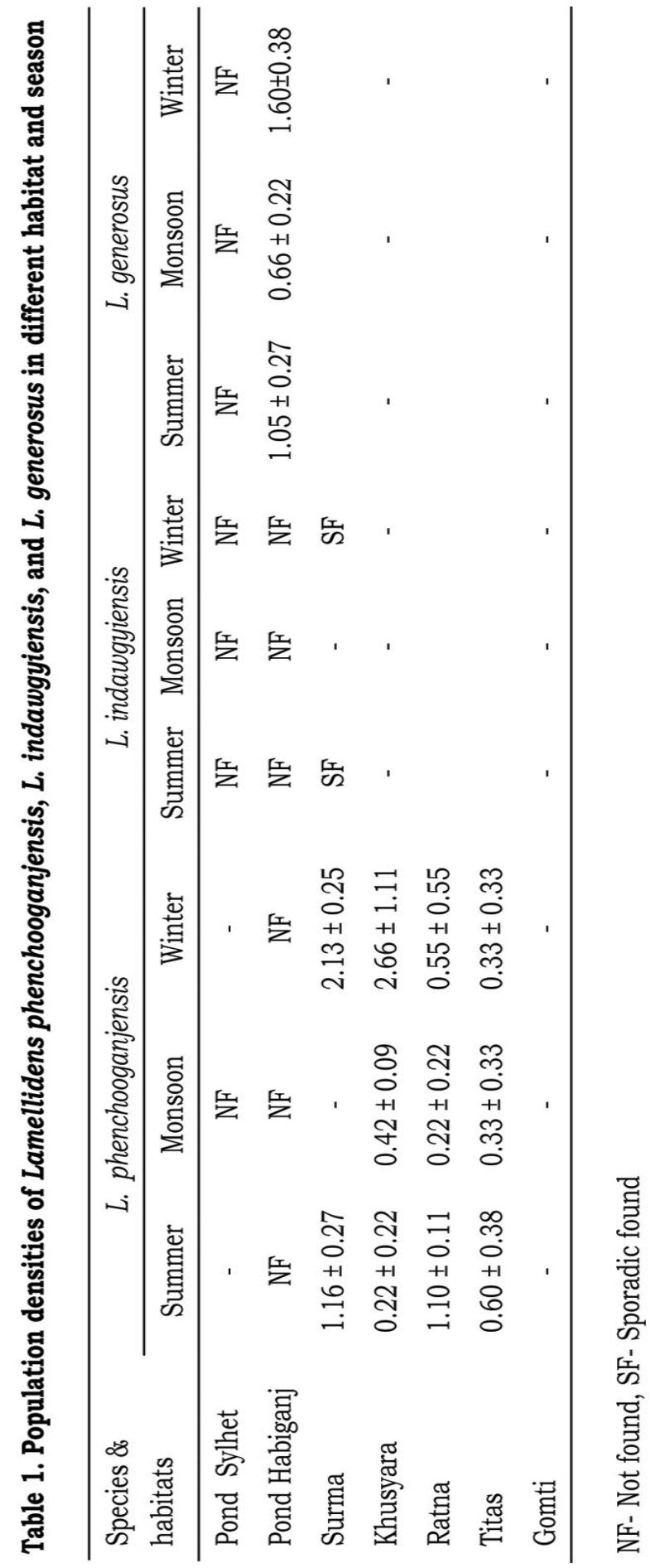




\section{Family: Unionidae}

Key to the species

1 Posterior wing developed L. generosus (Gould)

- Posterior wing feebly developed or absent

2 Posterior end elongate, shell narrow

- Posterior end not elongate, gradually sloped, shell broad

3 Shell elongately ovate, less thick umbones flat, anterior side angled, posterior margin obtusely rounded L. phencooganjensis Preston

- Shell transversely elongated, thick broader umbones, more distinct and convex, anterior end short and rounded, posterior side sloping L. jenkinsianus (Benson)

4 Shell broad, dorsal margin obliquely trunctate posterior end L. consobrinus (Lea)

- Shell narrower, dorsal margin gradually sloping posterior

5 Umbo prominent, colour brown with a lighter band along the margin L. marginalis (Lamarck)

- Umbo less prominent, colour uniformly dark L. corrianus

\section{Family: Amblemidae}

Genus: Parreysia

Key to Subgenera

1 Shell oval to elliptical, centre of ventral margin swollen, thick,

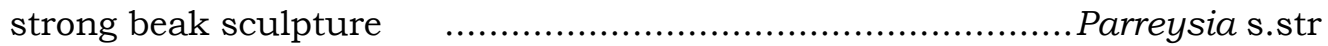

- Shell elongate, with almost straight ventral margin, comparatively thin, sculpture not so strong Radiatula Simpson

\section{Subgenus - Parreysia s.str.}

Key to Species

1 Central teeth very strong, 3 or more in number ............ . favidens (Benson)

- Central teeth very strong, less than 3 in numbers ..... P. corrrugata (Mueller)

Species 1. Lammelidens phenchooganjensis Preston, 1912

\section{Synonyms:}

1915. Lamellidens phenchooganjensis Preston, The Fauna of British India including Ceylon and Burma, Mollusca (Freshwater Gastropoda and Pelecypoda) London. Taylor and Francis, p 190.

English name: Freshwater mussel

Local name: Jhinuk, Chinai, Jhinai and Kafna

Description: Shell very elongate ovate. Pictorially obtusely rostrate dark blackish-brown, with umbones flat, much enrolled, anterior side angled above, 
gently rounded below posterior margin obtusely rounded antero-dorsal margin gently sloping, Postero-dorsal margin more rapidly sloping in slight curve. Anterior scars ovate moderately impressed; Posterior scars roughly triangular, not well impressed; interior of shell shading from plate brown to bluish, nacreous, and marked especially towards the anterior ventral region, with very shallow radiate furrows.

Size: Average adult valve length of shell and width are $87.33 \pm 15.85$ and $43.66 \pm 8.04 \mathrm{~mm}$ respectively.

Habit: Filter feeder, feeds on microscopic plants (diatoms), animals (Protozoa, water fleas, etc.) and organic detritus brought in current of water caused by cilliary movement.

Habitat: Found in rivers, haors, beel and streams. They are more abundant near the bank and bottom of the river.

Population density: The estimated population density of the mussel was highest minimum $\left(2.66 / \mathrm{m}^{2}\right)$ in winter in Khushyara River, Sylhet and minimum $\left(0.22 / \mathrm{m}^{2}\right)$ in summer in Khushyara River and Monsoon in Ratna Rive, Habiganj.

Distribution: Brahmanbaria, Habiganj, Maulvibazar and Sylhet Districts.

Elsewhere: India

Economic importance: Mussels flesh used as poultry feed. The shell is also used for ornamental inlay work, lime production, making buttons, knife handles etc.

Ecological role: They are filter feeder and act as natural water cleaner and indicator of water quality conditions.

Species 2. Lamellidens indawgyiensis Prasad, 1930

\section{Synonyms:}

1930. Lamellidens indawgyiensis, Prasad, Rec. Indian Mus., 32: 253, Pl. viii, figs 9, 10.

1989. Lamellidens indawgyiensis: Subba Rao, Hand Book of Fresh Water Molluscs of India, P. 166, Figs. 408, 409.

English name: Freshwater mussel

Local name: Jhinuk, Chinai, Jhinai and Kafna

Description: Shell large (more than $100 \mathrm{~mm}$ ) elongate-ovate, rather thick, moderately inflated surface with low, concentric ridges, umbones anterior not prominent, dorsal margin almost straight, ventral margin some what arched, anterior end short and broad, posterior rostrate, with well-marked post-dorsal wing.

Size: Average valve of adult shell length and width $106.00 \pm 19.80$ and $53.05 \pm$ $12.02 \mathrm{~mm}$ respectively. 
Habit: Filter feeder, feeds on microscopic plants (diatoms), animals (Protozoa, water fleas, etc.) and organic detritus.

Habitat: Found in aquatic habitat viz. lakes, rivers and streams. They are more abundant near the bank and bottom of the Beel and river.
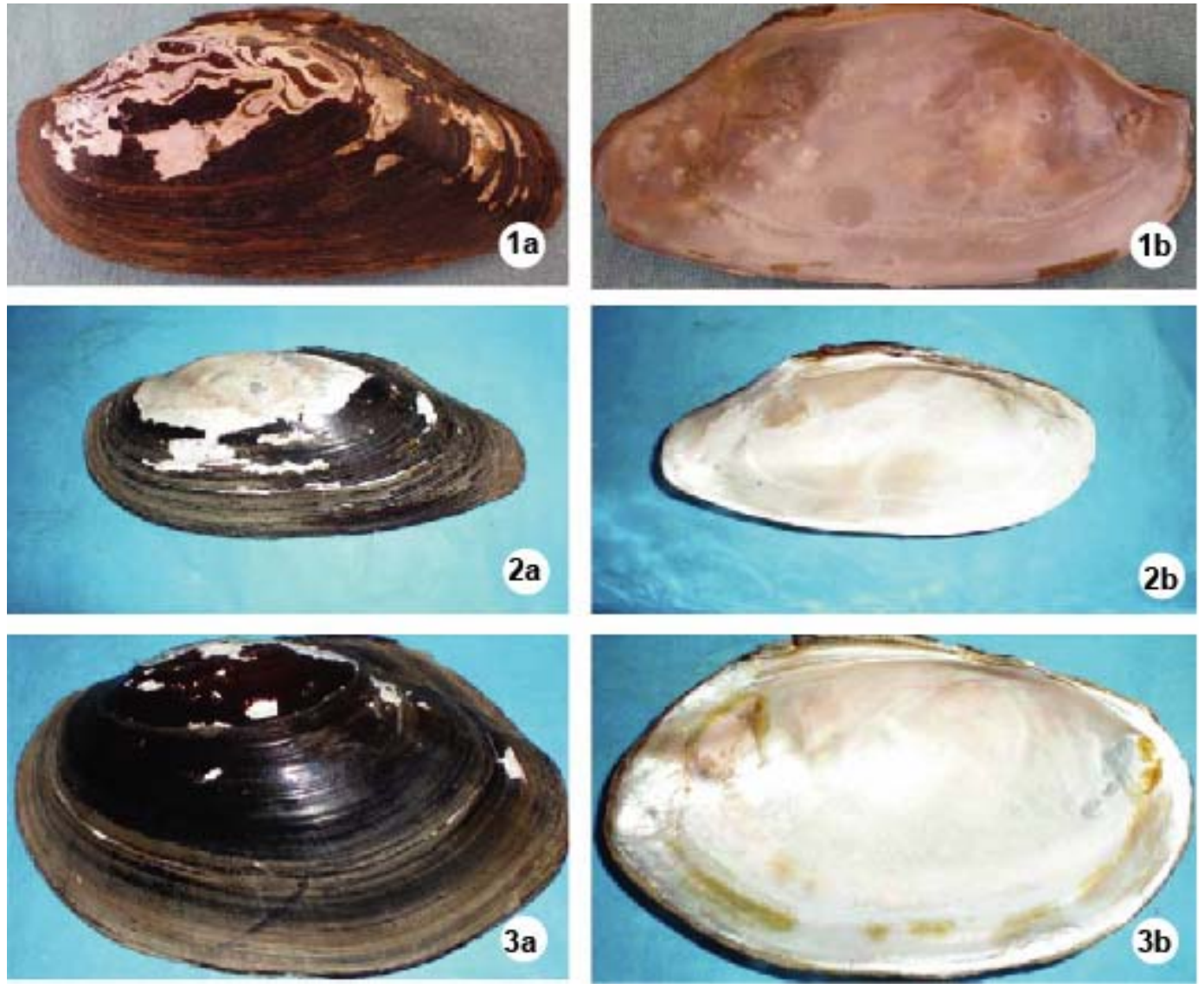

Plate 1. 1a. Outer View of Lamellidens phenchooganjensis (Scale: Length, $1 \mathrm{~mm}=1.27 \mathrm{~mm}$ and width, $1 \mathrm{~mm}=1.30 \mathrm{~mm}$ ), $1 \mathrm{~b}$ Inner View of $L$. phenchooganjensis (Scale: Length, $1 \mathrm{~mm}=1.16 \mathrm{~mm}$ and width, $1 \mathrm{~mm}=1.20 \mathrm{~mm}$ ), $2 \mathrm{a}$. Outer View of $L$. indawgyiensis (Scale: Length, $1 \mathrm{~mm}=1.93 \mathrm{~mm}$ and width $1 \mathrm{~mm}=2.12 \mathrm{~mm}$ ), Fig. $2 \mathrm{~b}$. Inner View of $L$. indawgyiensis (Scale: Length, $1 \mathrm{~mm}=2.03$ $\mathrm{mm}$ and width, $1 \mathrm{~mm}=2.22 \mathrm{~mm}$ ), 3a. Outer View of $L$. generosus (Scale: Length, $1 \mathrm{~mm}=1.12 \mathrm{~mm}$ and width $1 \mathrm{~mm}=1.07 \mathrm{~mm}$ ), Fig. $3 \mathrm{~b}$. Inner view of L. generosus, (Scale: Length, $1 \mathrm{~mm}=1.13 \mathrm{~mm}$ and width, $1 \mathrm{~mm}=1.04 \mathrm{~mm}$ )

Population density: These individuals were found occasionally; their population density was not determined.

Distribution: Habiganj, Maulvibazar and Sylhet districts.

Elsewhere: Myanmar 
Economic importance: Mussel flesh used as shrimp and poultry feed. The shell is also used for ornamental inlay work, lime production, making buttons, knife handles.

Species 3. Lamellidens generosus (Gould, 1847)

\section{Synonyms:}

1847. Unio generosus Gould. Proc. Boston Soc. nat. Hist., 2:220.

1922. Lamellidens generosus: Prasad, Rec. Indian Mus. 24: 107, Pl 2, Fig 12-17.

1989. Lamellidens generosus: Subba Rao, Hand Book of Fresh Water Molluscs of India, P. 165, Figs. 388, 389.

2004. Lamellidens generosus :Surya Rao, Mookerjee, Mitra, Manna and Barua, Fauna of Manipur, State Fauna Series, 10.p.86. Zool Surv. India.

English name: Freshwater mussel

Local name: Jhinuk, Chinai, Jhinai and Kafna

Description: Shell solid, oblong-ovate, anterior rounded posteriorly oblique subrostrate, dorsal margin straight, ventral margin arcuate, posterior wing narrow in adults.

Size: Average adult shell length and width about $79.2 \pm 20.74$ and $43.66 \pm$ $12.34 \mathrm{~mm}$ respectively.

Habit: Filter feeder, feeds on microscopic plants (diatoms), Protozoa, water fleas, etc.

Habitat: Found in aquatic habitat viz. ponds, lakes, rivers and streams. They are more abundant near the bank and bottom of the river.

Population density: These individuals were found occasionally. So their population density was not determined.

Distribution: Brahmanbaria and Habiganj, Maulvibazar and Sylhet District.

Elsewhere: India, Myanmar.

Economic importance: Mussel flesh used as shrimp and poultry feed. The shell is also used for ornamental inlay work, lime production, making buttons, knife handles, etc. Lamellidens generosus are edible food to people of Manipur (States of India).

Species 4. Parreysia (Parreysia) favidens var. assamensis Preston, 1912 Synonyms:

1989. Parreysia (Parreysia) favidens subsp. assamensis: Subba Rao, Handbook Freshwater Molluscs of India P. 181, figs. 468, 469. 
2000. Parreysia (Parreysia) favidens subsp. Assamensis: Takur et al. Fauna of Tripura, State Fauna Series, 7, p.337, Zool.Surv. India.

English name: Freshwater mussel

Local name: Gol jhinuk, Sobuj jhinuk
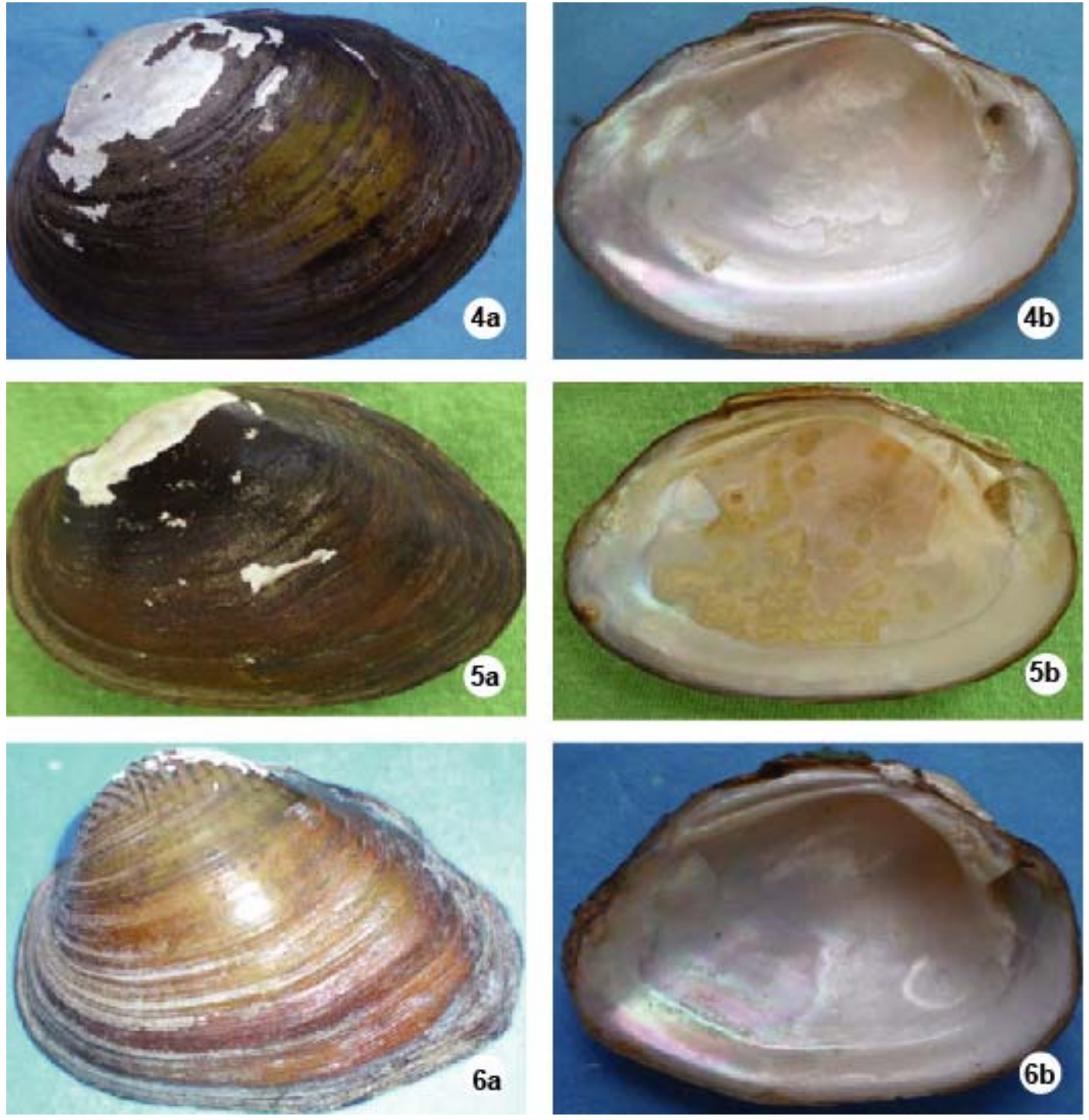

Plate 2. 4a. Outer view of Parreysia favidens var. assamensis, Fig. 4b. Inner view of $P$. favidens var. assamensis (Scale: Length, $1 \mathrm{~mm}=0.68 \mathrm{~mm}$ and Width $1 \mathrm{~mm}=0.62 \mathrm{~mm}$ ), Fig. 5a. Outer view of $P$. (P.) favidnes var. marcens (Scale: Length, $1 \mathrm{~mm}=0.74 \mathrm{~mm}$ and width $1 \mathrm{~mm}=0.78 \mathrm{~mm}$ ), $5 \mathrm{~b}$. Inner view of $P$. (P.) favidens var. marcens (Scale: Length, $1 \mathrm{~mm}=0.80 \mathrm{~mm}$ and width $1 \mathrm{~mm}=0.80$ $\mathrm{mm}$ ), 6a. Outer View of $P$.(P.) viridula, 6b. Inner View of $P$. (P.) viridula (Scale: Length, $1 \mathrm{~mm}=0.70$ $\mathrm{mm}$ and width $1 \mathrm{~mm}=0.66 \mathrm{~mm}$ ) 
Description: Shell more convex that typical from, dorsal margin rather less posterior angled, anterior side is more rounded and posterior slightly more nauseate.

Size: Average adult valve length and width about $48.33 \pm 0.77$ and $30.41 \pm$ $3.95 \mathrm{~mm}$ respectively.

Habit: Filter feeder, feeds on microscopic plants (diatoms), animals and organic detritus brought in through current of water.

Habitat: The specimens found in aquatic habitat viz. lakes, ponds, rivers and streams. It lives nearly buried in mud or sand bottom, with only the posterior tips of the shell valves exposed.

Population density: The species have been collected sporadically. So the population density was not estimated.

Distribution: Brahmonbaria, Comilla and Sylhet Districts.

Elsewhere: Assam: Digong; Bihar: Arrah; Mizoram and Tripara (Indian states).

Economic importance: Mussel's flesh used as shrimp and poultry feed, crushed shell used as poultry feed ingredients. The shell is also used for ornamental inlay work, lime production, making buttons, knife handles, etc.

Ecological role: These mussels are filter feeders and acts as natural water cleaner and indicators of water quality conditions.

\section{Species 5. Parreysia (Parreysia) favidens var. marcens Benson 1862 Synonyms:}

1862. Unio favidens var. marcens Benson, Ann. Mag. nat. Hist., 3(10): 188.

1992. Parreysia (Parreysia) favidens var. marcens :Mitra and Dey, State Fauna Series, 3: Fauna of West Bengal, part 9:31, Zool.Surv. India.

2005. Parreysia (Parreysia) favidens var. marcens :Ramakrishna et al., Fauna of Andhra Prodesh, State Fauna Series, 5(Part-5), p.215, Zool.Surv. India.

English name: Freshwater mussel

Local name: Gol jhinuk

Description: Shell large, more elongate dark brown, umbonal region weakly sculptured, posterior margin broadly rounded.

Size: Average adult valve length and width about $52.30 \pm 8.02$ and $33.44 \pm$ $5.69 \mathrm{~mm}$ respectively.

Habit: Filter feeder, feeds on microscopic plants (diatoms), animals and organic detritus brought in through current of water. 
Habitat: The specimens found in aquatic habitat viz. lakes, rivers and streams. It lives nearly buried in mud or sand bottom, with only the posterior tips of the shell valves exposed.

Population density: The species have been collected sporadically. So the population density was not estimated.

Distribution: Comilla, Sylhet.

Elsewhere: Andra Pradesh: Khammam, Srikakulum, Assam, Maharashtra, West Bengal: Bardhaman, Kolkata.

Economic importance: Mussel's flesh used as shrimp and poultry feed, crushed shell used as poultry feed ingredients. The shell is also used for ornamental inlay work, lime production, making buttons, knife handles, etc.

Ecological role: These mussels are filter feeders and acts as natural water cleaner and indicators of water quality conditions.

\section{Species 6. Parreysia (Perreysia) favidens var. viridula Benson, 1862 Synonyms:}

1862. Parreysia favidens var. viridula Benson, Ann. Mag. nat. Hist., 10(3): 189.

1989. Parreysia favidens var. viridula : Subba Rao Handbook Freshwater Molluscs of India P. 182, figs. 474, 475.

English name: Freshwater mussel

Local name: Gol Jhinuk

Description: Shell compressed; cardinal teeth broad; nacre bluish white; umbonal rugae strong and extended.

Valve length and width and thickness about $47.5 \pm 0.7$ and $30.50 \pm 0.7 \mathrm{~mm}$ respectively.

Habit: They are too filter feeder, feeds on microscopic plants (diatoms), animals and organic detritus brought in through current of water.

Habitat: The specimens found in aquatic habitat viz. lakes, rivers and streams. It lives nearly buried in mud or sand bottom, with only the posterior tips of the shell valves exposed.

Population density: The species have been collected sporadic. So the population density was not estimated.

Distribution: Sylhet (Fenchugonj).

Elsewhere: India

Economic importance: Mussel's flesh is uses as shrimp and poultry feed, crushed shell used as poultry feed ingredients. The shell is also used for ornamental inlay work, lime production, making buttons, knife handles, etc. 
Ecological role: These mussels are filter feeders and acts as natural water cleaner and indicators of water quality conditions.

In the present study and past is total of 22 freshwater bivalves were recorded from the different habitats of Bangladesh. Out of these, ten species were reported by Ali and Begum (1976) and Begum et al. (1989). In this study six new records were reported from Bangladesh. $P$. (R) caerulea sub sp. gaudicahaudi, $P$. (R.) occata and Pisidium clarkeanum were reported earlier in Fauna of British India from the study area but did not encounter during the present investigation.

Freshwater mussels are a guild of sedentary, suspension feeding bivalves that perform import functions in lakes and streams (Vaughn and Hakenkamp 2001). These large, long lived invertebrates can be considered ecosystem engineers because they modify habitat, making it more suitable for conspecifics and other organisms (Gutierrez et al. 2003 and Spooner and Vaughan 2006). Mussels transfer nutrients and energy from the water column to the sediments through their filtering and stimulate production across trophic levels (Howard and Cuffey 2006, Spooner and Vaughan 2006, Vaughan et al. 2007). The decline of bivalve mollusc is driven by habitat degradation and siltation of pond, rivers and other aquatic habitat. Pollution from industries, agriculture and erosion have serious threat to gastropod and mussels. To explore and conservation of freshwater mussel in the Bangladesh is urgently needed and more comprehensive studies should be carried out.

\section{LITERATURE CITED}

ALI, S. and BEGUM, M. 1976. Freshwater molluscs of Dhaka city with notes on their ecology. J. Asiat. Soc. Bangladesh. 2: 29-36.

BEGUM, M., ISMAIL, M., and ALI, S., 1989. A note on freshwater mussel of Bangladesh. Bangladesh J. Zool. 17(2): 203-204.

BEGUM, M., ISMAIL, M., ALI, S., ISLAM, Z. and PAGGATIPUNON, R. N. 1990. Studies on pearl culture in freshwater mussel, Lamellidens marginalis (Lamark). Bangladesh J. Zool. 18(2): 223-227.

CUMMINGS, K.S., and GRAFT, D.I., 2005. Global distribution of freshwater mussel diversity. In: 4th Biennial Symposium, freshwater Molluscs Conservation Society, 15-18 May, St. Paul, Minnesota:35 [abstract].

GUTIERREZ, J.L., JONES, C.G., STRATER, D.L. and IRIBARNE, O.O. 2003. Mollusks as ecosystem engineers: the role of shell production in aquatic habitats. Oikos. 101: 79-90.

HOWARD, J.K. and CUFFEY, K.M. 2006. The functional role of native freshwater mussels in the fluvial benthic environment. Freshwater Biology. 51: 460-474.

HUA DAN, MAZID, M.A. and HUSSAIN, M.G.2001. Freshwater Pearl Culture, Principles and Techniques. Bangladesh Fisheries Research Institute, Mimensingh, 2201, Bangladesh, p, 104. 
IMLAY, M.J.1982.Use of shells of freshwater mussels in monitoring heavy metals and environmental stress: a review. Malacological Review, 15: 1-14.

MATCALFE, S.J.L. and GREEN, R.H.1992.Ageing Studies on three species of freshwater mussels from a metal-polluted watershed in Nova Scotia, Canada. Canadian J. Zool. 70(7): 1284-1291.

PRESTON, H.B. 1915. The Fauna of British India, Including Ceylon and Burma, Mollusca. Today and Tomorrow's Printers and publishers, New Delhi-110005. pp. XVIII.

OUTEIRIO, A.O., ONDINA, P., FERNANDEZ, C., AMARO, R. and MIGUEL, E.S. 2008. Population density and age structure of the freshwater pearl mussel Margaritifera margaritifera, in two Iberian rivers. Freshwater Biology. 53: 485- -496.

PEREZ-QUINTERO,J.C., 2011. Freshwater mollusks biodiversity and Conservation in two stressed Mediterrenian basins. Limnologica 41: 201-212.

RAMAKRISHNA and DEY, A. 2007. Hand book on Indian Freshwater Molluscs, Zoological Survey of India, Kolkata,. $386 \mathrm{pp}$.

SUBBA R.N.D. 1989. Hand book of freshwater Molluscs of India, Zoological Survey of India, Calcutta. 290pp.

SPOONER, D.E. and VAUGHN, C.C. 2006. Context-dependent effects of freshwater mussels on the benthic community. Freshwater Biology. 51:1016-1024.

SIDDIQUI, K.U., ISLAM, M.A., KABIR, S.M.H., AHMAD. M., AHMED A.T.A., RAHMAN, A.K.A., HAQUE, E.U., AHMED, Z.U., BEGUM, Z.N.T., HASSAN M.A., KODOKER, M. and RAHMAN, M. M. (eds). 2007. Encyclopedia o Flora and Fauna of Bangladesh. Vol. 17. Molluscs. Asiatic Society of Bangladesh, Dhaka 415pp.

VAUGHN, C.C. and PYRON, M. 1995. Population ecology of the endangered Ouachita Rock Pocketbook mussel, Arkansia whleeleri (Bivalvia: Unionidae), in the Kiamichi River, Oklahoma. American Malacological Bulletin 11: 145-151.

VAUGHN, C. C. and HAKENKAMP, C.C. 2001. The functional role of burrowing bivalves in freshwater ecosystems. Freshwater Biology. 46: 1431-1446.

VAUGHN, C.C., SPOONER, D.E. and GALBRAITH, H.S. 2007. Context depend species identify effects within a functional group of filter-feeding bivalves. Ecology, 88: 1662-1664.

VAUGHN, C.C., NICHOLS, S.J. and SPOONER, D.E. 2008. Community and food web ecology of freshwater mussels. J.N. Am. Benthol. Soc. 27(2): 409-423.

WACHTLER, K.M.C., DREHER, M. AND RICHTER, T. 2001. Larval types and early postlarval biology in Naidas (Unionoida). In: BAUER,G. and K.WACHTLER (eds), Ecology and Evolution of Freshwater Mussel, Unionoida. Ecological Studies, Springer-Verlag, Berlin, 145: 95-125. 